\title{
Empathetic doctor - the role and the significance of the empathy in the doctor-patient relation
}

\author{
Sylwia Królak
}

Gdyńskie Centrum Zdrowia

Address for correspondence: Gdyńskie Centrum Zdrowia, ul. Władysława IV 43, 81-395 Gdynia, sylwiakrolak@op.pl

\section{Abstract}

The article attempts to demonstrate the significance and value of empathy in the medical profession, and the consequences generated by its absence, or its very high level. In psychology, empathy is considered to be a multidimensional phenomenon, affecting the appropriate interpersonal relations. Understanding one's emotions is vital in recognizing the emotions of others. Empathy is one of the emotions acquiring particular significance in the medical profession. Highly empathetic doctor is the dream of every patient.

Unfortunately, a too high level of empathy and the lack of emotional self-regulation skills can lead a physician to empathic depression, and even professional burnout. The article presents research results reflecting the level of empathic sensitivity for the scales of Empathic Concern, Personal Distress and Perspective Taking. The study used Empathic Susceptibility Scale SWE (Kaźmierczak, Plopa, Retowski, 2007), and the respondents were 80 doctors working in one of the hospitals in Gdynia in 2013.

Key words: empathy, physician, patient, doctor-patient relation, Empathetic Susceptibility Scale (ESS), emotional depression, professional hurnout

Stowa kluczowe: empatia, Iekarz, pacjent, relacja lekarz-pacjent, Skala Wrażliwości Empatycznej, przygnębienie emocjonalne, wypalenie zawodowe

\section{Introduction}

Man as a social being is continually entering into relationships with another man on many levels of professional and personal life. It should be noted that it is egoism, depersonalization of man and indifference to others that are increasingly dominating in social relationships. Selfish approach to life, in turn, deprives the society of sensitivity. The ability to interact with others and the right way of communicating will lead to the accomplishment of common goals, thus giving people a chance to achieve full satisfaction. It should be taken into consideration that emphatic people are more popular, they gain more trust and they have the ability to motivate others to engage in the activity yielding better results and opening the way to success in the professional, social and personal sphere [1].

Apart from competences directly connected with a profession, modern times oblige employees to develop special skills which not only set them apart from their coworkers, but also help increase their efficiency.
In this article an attempt has been made to define the meaning of empathy in doctor-patient relations as well as to examine the level of empathic sensitivity in doctors in regard to their gender, age and specialty.

\section{The significance of empathy in the doctor's profession}

It has been believed until recently that the rational, analytical way of thinking which is in line with the generally accepted rules is the best and the most effective one. Emotions have been consciously ignored in an attempt to maintain full objectivity of the situation. It has been noted, however, that genuine social value can be attained only when emotions and reason are combined in an intelligent way. Therefore, emotional intelligence is getting more and more significant, while the lack of appropriate emotional competences may lead to a situation in which an employee will not be able to carry out the assigned tasks successfully [2].

Emotional intelligence determines a potential to attain practical skills which are based on five components: 
self-awareness, self-regulation, motivation, empathy and appropriate interaction with others. A high level of emotional intelligence in itself does not guarantee that its owner will be able to make use of emotional skills in the workplace, but it may mean that such a person has good learning opportunities to master the required skills. The necessary condition for reaching the emotional area of other people is having very good knowledge of one's own emotions [3]. Emotional intelligence helps us move in the world of interpersonal relationships and empathy is its inseparable element.

The early mention of empathy can be found in the works of ancient philosophers, e.g. in Aristotle's Rhetoric, while stoics understood empathy as a spiritual community of all things that make people sympathize with each other [4]. The term "empathy" derives from "Einfühlung" and originally it meant an inclination of an observer to identify with the observed object, making them experience beauty. At the turn of the $19^{\text {th }}$ century, in Germany, the trend of the so-called esthetic empathy represented by Theodor Lipps was developed. Lipps used this term in his research on the processes responsible for getting to know people. The English term empathy was invented by Titchener, as a translation of the notion of Einfühlung applied by Lipps [5]. Currently, treating empathy as a simple emotional reaction to emotional signals of another person and understanding it entirely in intrapsychic categories is being abandoned [4]. Davis [5] defines empathy as a "set of theoretical constructions which refer to reactions of an individual to the experience of others". To the above mentioned constructions Davis included processes taking place in the observer together with the affective and non-affective outcomes of these processes. The ability to feel empathy is associated with biological factors connected with the body functioning and the social processes responsible for learning (sharing similar experience, structure and biological functions and also being vulnerable to similar environmental influences) [6]. The research findings show that a mirror neuron system MNS may be employed in the process of the creation of empathy. The operational mechanism of MNS is based on the "mirror" principle and is also the fact that we are able to imitate and share affective states of others by mere observation [7]. According to Goleman [1], the term "empathy" is associated with three other meanings.

1. Empathy as knowledge of what another person is feeling.

2. Empathy as feeling what another person is feeling.

3. Empathy as reacting with sympathy to another person's pain.

It was the complexity of empathy that made it attractive for Organizational/Industrial Psychology which acknowledges its significant role in the professional development of a present-day employee [8]. Being based on emotional awareness, empathy is a fundamental skill for social interaction. People who have the ability to empathize may be more sensitive to subtle interpersonal signals pointing to the needs of others; that is why they succeed in the professions requiring care and consideration of others [9]. According to Goleman [3], empathy is a skill which acts as a foundation for all important competencies at work which include the following:

1. Understanding others - understanding the point of view of others, sensing their feelings and taking active interest in their problems.

2. Service approach - recognizing and fulfilling the needs of other people.

3. Shaping others - sensing in others the need for development, shaping their abilities, motivating to work.

4. Supporting diversity - taking interest in cooperation with people equipped in various skills.

5. Political awareness - focusing on social or organizational interaction in relation to an individual.

Goleman remarks that the ability to discern real emotions is particularly important when people have reasons to hide their genuine feelings [3]. Anxiety, worry and apprehension are all emotions connected with discomfort of the diagnosing process and treatment, which may lead to blocking of the actual emotions developing in a patient. In such a situation, the task of a doctor is to observe the patient's behaviour displaying sensitivity to the emotional signals and to pay particular attention to what the patient is saying or trying to hide from the doctor.

Jagielska-Zieleniewska believes, that the ability to emphathize is the factor that determines the expressive role of the doctor which facilitates shaping a positive therapeutic relationship based on the correct understanding of a patient and their psychosocial conditioning and decisively affects altruistic behaviours which restrain aggressive reactions [10]. It is also believed that the higher emphatic skills, the more perfect relationship with the patient in terms of verbal and non-verbal communication, safeguarding against the creation of stereotypes and following the routine in relations with a patient [6]. Leder remarks that after visiting a doctor, patients find it much easier to describe the doctor's emotional state and their attitude to them than the content of their exchange. Hence the conclusion that doctor's behaviour should be consistent with the message they convey to the patient [4].

The ability to recognize one's own and other people's emotional states may condition the correct perception of the affective sphere of a patient; therefore the higher level of empathy the better perception of one's own and other people's emotional states [10]. Through the study of the patient's level of satisfaction from a visit to the doctor, and from the medical and psychological care they were offered, it was revealed that the level of empathy has an impact on the doctor's professional workload. A satisfied patient visited their doctor only for the scheduled appointments, whereas when their needs were unsatisfied, they were inclined to pay more frequent visits. According to research results, the more emphatic the doctor, the lower their workload [10]. Emotional support rises in val$\mathrm{ue}$, when the patient is given a chance to talk about their illness and the accompanying emotions. It is the doctor's duty to accept the patient together with their limitations, to offer them honesty in their relationship and to help create a strong emotional bond. An honest talk, understanding and sensing the patient's needs are sufficient for the patient to cope with the stress which is accompa- 
nying their illness and to relieve negative emotions. An emphatic listener will undoubtedly find out quickly what the patient's expectations are and what they are willing to talk about [11]. Bellet and Maloney are of the opinion that the essential skill necessary to establish medical history is the ability develop empathy thanks to which it is possible to understand patients to the full. The best test for the effectiveness of empathy would be to find out to what extent doctor's answers stimulate and deepen the patient's course of narrative [12]. A high level of doctor's empathy will be beneficial for the patient, but it can also bring negative effects for the doctor.

A high level of empathy may cause depression, which in most cases develops when we are deeply affected by other people's suffering. This phenomenon takes place when a person with strongly developed ability to emphasize is exposed to negative moods of another person but is not equipped in the self-regulatory skills that will allow them to control depression which is the outcome of compassion [3]. Long-term emphatic depression stifles sensitivity even in the most devoted doctor and emotional exhaustion will lower empathy towards a patient which, in turn, may lead to a professional burnout. According to Jakubowska-Winecka, burnout is characterized by chronic fatigue, which prevails even after relaxation, low mood and the deterioration of physical functioning. Working in healthcare is connected with a specific type of stress deriving from constant closeness to the patient, the level of risk and responsibility, the outcome of continuous contact with pain and suffering or the necessity to break a barrier of privacy of another person. Professional burnout may develop together with the experience of long-lasting failure in combination with simultaneous struggle against stress [13]. Other factors that have impact on professional burnout include the sense of failure in relation to one's own expectations connected with professional life, a low level of clinician's control over the performed work and the lack of emotional support for the doctor [14]. Experiencing pain and suffering simultaneously with the patient, and sometimes the lack of hope for the patient's recovery are for the medical staff a heavy burden and expose them to continuous emotional stress. The feeling of helplessness reaches the culminating point when the expectations of a patient are beyond the scope of medicine. Excessive demands imposed by patients, which can be interpreted by doctors as questioning their authority, also make therapists experience negative emotions. Too long working hours, too heavy workload or lack of recognition from superiors may also contribute to burnout which may additionally be conditioned by individual internal factors such as beliefs or self-esteem [15]. Stress is a strong indicator of the lack of job satisfaction. It is considered that working in the medical profession is directly connected with stress, but since the choice of this profession is dictated by very strong motivation, it is this same motivation that can help lower the high level of professional stress [16].

An emphatic relationship with a patient producing effective verbal and emotional communication may become the main tool in therapy, in particular for patients suffering from illnesses with bad prognosis, chronic illnesses or for terminally-ill patients. The basic task of a doctor in such circumstances will be to reduce the patient's nervous tension, to fulfil their cognitive needs and help understand the significance of an illness and the whole process of treatment [10]. Carl Rogers notices that his patients felt better when they were created favourable conditions to express themselves safely. The list of these conditions is as follows: the appropriateness of doctor's behaviour, the unconditionally positive attitude to patients and full of empathy understanding [11]. Having knowledge about the current feelings and the typical forms of behaviour of other people it is possible to shape effectively people's opinions as well as to influence their behaviour and attitudes [2].

\section{Own research findings}

In the conducted research the Scale of Emphatic Susceptibility test was used [17]. The above mentioned tool provides the measures of dispositional emphatic sensitivity and includes three separate scales relating to separate aspects of empathy:

1. The Scale of Taking Perspective (TP) - measures the ability and tendency to spontaneous adoption of the psychological point of view of other people in ordinary life situations.

2. The Scale of Emphatic Concern (EC) - assesses the tendency to be compassionate and sympathetic towards the people who experienced failure.

3. The Scale of Personal Distress (PD) - is connected with a tendency to feel distress and discomfort as a reaction to strong negative experiences of other people [5].

Kaźmierczak, Plopa and Retowski conducted research in which they correlated the SES Scale with measures of different personal characteristics. In the research the 16 PF-5 Personality Questionnaire by R.B. Cattel and co-workers was used which is composed of 16 factors relating to different personal characteristics: Warmth (A), Reasoning (B), Emotional Stability (C), Dominance (E), Liveliness (F), Rule-Consciousness (G), Social Boldness (H), Sensitivity (I), Vigilance (L), Abstractedness (M), Privateness (N), Apprehension (O), Openess (Q1), SelfReliance (Q2), Perfectionism (Q3), Tension (Q4), as well as five global factors: Extraversion (EX), Anxiety (AX), Tough-Mindedness (TM), Independence (IN), Self-Control (SC). It has been noted that Emphatic Concern correlates positively with the " $A$ " factor - Warmth, the " $F$ " factor - Liveliness (enthusiasm, spontaneity)), the " $O$ " (Apprehension) factor (tendency to worry, anxiety), the "G" (Rule-Consciousness) factor (following the socially accepted rules and behaviours), the "I" (Sensitivity) factor (sentimentality, sensitivity), the " $\mathrm{M}$ " factor (Abstractedness) (vivid imagination). Negative correlations, on the other hand, were established with Privateness (N) - discretion, avoiding intimacy with others, and with Self-Reliance (Q2) - preference for independent work. Personal Distress achieved the highest correlations with the "O" (Apprehension) factor and with the "Q4" factor - 
Tension (tendency to irritability and continuous nervous tension). A negative correlation was observed between the Personal Distress index and the " $\mathrm{C}$ " factor - Emotional Stability , " $H$ " factor - Social Boldness and "Q1" factor - Openness. It has been noticed that people who reached high results on the Scale of Taking Perspective are kind and understanding to others which is represented by high " $A$ " factor correlation and the above mentioned scale. The Scale of Taking Perspective correlates positively with the " $H$ " factor - Social Boldness, the "Q1" factor - Openness, and the "G" factor - Rule-Consciousness. Negative correlations were obtained with the "N" factor - Privateness, the "Q2" factor - Self-Reliance and the "Q4" factor - Tension [18]. The correlations of SES scales with the 16 PF-5 questionnaire are presented in Table I.

The researched group consisted of people with higher medical education (physicians) with a valid license for medical practice and currently employed. The researched group was limited to doctors employed by the one of the hospitals in Gdynia in 2013. The test was completed by 80 doctors with the following specialties: anesthesiology, intensive care, surgery including general surgery, onco- logical surgery, internal medicine, oncological gynecology, clinical oncology, pediatrics, gynecology and obstetrics, pulmonary medicine, radiology, diagnostic imaging, oncological radiotherapy and the doctors in the course of doing specialties.

The respondents marked one value on a scale for each statement and they followed the following criteria:

- I disagree;

- I slightly disagree;

- I neither agree nor disagree;

- I slightly agree;

- I agree.

The answers were allocated the following score in points:

- I disagree = 1 point;

- I slightly disagree = 2 points;

- I neither agree nor disagree $=3$ points;

- I slightly agree = 4 points;

- $\quad$ I agree $=5$ points

to order the answers on a scale from the lowest to the highest score.

The data gathered from a group of 80 doctors representing different specialties was analysed in Table II.

\begin{tabular}{|c|c|c|c|}
\hline \multirow{2}{*}{$\begin{array}{c}16 \mathrm{PF}-5 \\
+ \text { global factors }\end{array}$} & \multicolumn{3}{|c|}{ SES (Scale of Empathic Susceptibility) } \\
\hline & Empathic concern & Personal distress & Taking perspective \\
\hline A-warm & $0.37 * *$ & 0.00 & $0.26^{* *}$ \\
\hline $\mathrm{B}$ - reasoning & -0.11 & -0.14 & 0.09 \\
\hline $\mathrm{C}$ - emotional stability & -0.11 & $-0.51 * *$ & 0.09 \\
\hline $\mathrm{E}$ - dominance & 0.06 & -0.15 & 0.09 \\
\hline $\mathrm{F}$ - liveliness & $0.22 * *$ & -0.03 & 0.10 \\
\hline $\mathrm{G}$ - rule-consciousness & $0.17 *$ & 0.02 & $0.19^{*}$ \\
\hline $\mathrm{H}$ - social boldness & 0.12 & $-0.41 * *$ & $0.31 * *$ \\
\hline I- sensitivity & $0.17 *$ & $0.20^{*}$ & 0.00 \\
\hline $\mathrm{L}$ - vigilance & -0.14 & 0.03 & -0.07 \\
\hline M - abstractedness & $0.17 *$ & 0.06 & 0.02 \\
\hline $\mathrm{N}$ - privateness & $-0.30^{* *}$ & -0.05 & $-0.26^{* *}$ \\
\hline $\mathrm{O}$ - apprehension & $0.40 * *$ & $0.53 * *$ & 0.13 \\
\hline Q1 - openess & 0.15 & $-0.26^{* *}$ & $0.20^{*}$ \\
\hline Q2 - self-reliance & $-0.36^{* *}$ & -0.13 & $-0.23 * *$ \\
\hline Q3 - perfectionism & 0.14 & 0.15 & 0.15 \\
\hline $\mathrm{Q} 4$ - tension & 0.00 & $0.32 * *$ & $-0.19^{*}$ \\
\hline EX - extraversion & $0.36^{* *}$ & -0.05 & $0.31 * *$ \\
\hline $\mathrm{AX}-$ anxiety & 0.14 & $0.54 * *$ & -0.12 \\
\hline TM - tough-mindedness & $-0.31 * *$ & 0.02 & $-0.17 *$ \\
\hline IN - independence & 0.09 & $-0.30 * *$ & $0.19 *$ \\
\hline $\mathrm{SC}$ - self-control & 0.01 & 0.04 & 0.12 \\
\hline
\end{tabular}

$* p<.05 ; * * p<.01$

Table I. Correlations of the SES scales with the 16 PF-5 questionnaire.

Source: Kaźmierczak M., Plopa M., Retowski S., Skala Wrażliwości Empatycznej (The Scale of Emphatic Susceptibility), "Przegląd Psychologiczny" 2007; 50 (1): 18, 20 [17]. 


\begin{tabular}{|c|c|c|c|}
\hline & & Size & Percentage \\
\hline \multirow[t]{3}{*}{ Gender } & Female & 42 & $52.50 \%$ \\
\hline & Male & 38 & $47.50 \%$ \\
\hline & Total & 80 & $100.00 \%$ \\
\hline \multirow[t]{6}{*}{ Age } & $<30$ years & 16 & $20.00 \%$ \\
\hline & $31-40$ years & 17 & $21.25 \%$ \\
\hline & $41-50$ years & 22 & $27.50 \%$ \\
\hline & $51-60$ years & 16 & $20.00 \%$ \\
\hline & $61<$ & 9 & $11.25 \%$ \\
\hline & Total & 80 & $100.00 \%$ \\
\hline \multirow[t]{12}{*}{ Medical specialty } & Anesthesiology and intensive care/critical care & 6 & $7.50 \%$ \\
\hline & Surgery & 11 & $13.75 \%$ \\
\hline & Internal medicine & 9 & $11.25 \%$ \\
\hline & Oncological gynecology & 8 & $10.00 \%$ \\
\hline & Clinical oncology & 5 & $6.25 \%$ \\
\hline & Pediatrics & 5 & $6.25 \%$ \\
\hline & Gynecology and obstetrics & 8 & $10.00 \%$ \\
\hline & Pulmonary medicine & 6 & $7.50 \%$ \\
\hline & Radiology and diagnostic imaging & 7 & $8.75 \%$ \\
\hline & Oncological radiotherapy & 5 & $6.25 \%$ \\
\hline & Without specialty & 10 & $12.50 \%$ \\
\hline & Total & 80 & $100.00 \%$ \\
\hline
\end{tabular}

Table II. A detailed structure in terms of gender, age and medical specialty.

Source: Own work.

Statistical comparison was carried out by means of the t-Student test, a single-factor analysis of ANOVA variance with the assumed level of significance $p=.05$.

Table III depicts descriptive statistics of the level of emphatic sensitivity in doctors, including minimum, maximal and mean values and standard deviation.

\section{The relation between gender and emphatic sensitivity in doctors}

The analysis conducted by means of the t-Student test for two independent trials has revealed that statistically gender significantly differentiates the level of taking perspective in doctors. The probability value for the twosided test equals 0.006 , and since the level of significance is $p=.05$, it indicates that gender has impact on the mean value of the level of taking perspective. No statistically significant differences between male and female doctors have been observed in relation to mean values of emphatic concern and personal distress. The results are presented in Table IV.

A single-factor analysis of ANOVA variance has revealed that statistically age does not differentiate significantly the level of emphatic sensitivity presented on the scales of Emphatic Concern, Personal Distress and Taking Perspective (Table V). Regardless of age, doctors demonstrate a similar level of empathic sensitivity.

\section{The relation between specialty and emphatic susceptibility in doctors}

A single-factor analysis of ANOVA variance has revealed that statistically medical specialty significantly differentiates the level of taking perspective. No differentiating influence of specialty on the level of emphatic concern or personal distress has been observed (Table VI).

Post-hoc comparisons, with the Bonferroni's correction have revealed the existence of statistically significant differences between doctors with and without specialty in the field of pediatrics and between doctors specializing in pediatrics and those with specialty in oncological radiotherapy. Doctors specializing in pediatrics reveal a significantly higher level of taking perspective in comparison with physicians without specialty and doctors with specialty in oncological radiotherapy. On the other hand, doctors show a similar level of emphatic concern and personal distress, regardless of their specialty.

It would be also worthwhile to draw attention to the ANOVA variance analysis results, which show that a specialty in female doctors differentiates statistically a significant level of emphatic sensitivity presented on the Personal Distress Scale. The results are shown in Table VII. 


\begin{tabular}{|l|c|c|c|c|cc|}
\hline & N & Min. & Max. & M & SD \\
\hline Empathic concern & 80 & 19 & 54 & 40.59 & 6.89 \\
\hline Personal distress & 80 & 9 & 35 & 19.80 & 5.91 \\
\hline Taking perspective & 80 & 25 & 45 & 34.59 & 4.95 \\
\hline
\end{tabular}

Table III. Descriptive statistics of emphatic sensitivity in doctors.

Source: Own work.

\begin{tabular}{|c|c|c|c|c|c|c|}
\hline & & \multicolumn{2}{|c|}{ Gender } & \multicolumn{3}{|c|}{ Statistics $t$} \\
\hline & & Female doctors & Male doctors & $t$ & $d f$ & $p$ \\
\hline \multirow[t]{2}{*}{ Empathic concern } & M & 42.00 & 39.03 & 1.96 & 78 & .053 \\
\hline & SD & 6.79 & 6.75 & & & \\
\hline \multirow[t]{2}{*}{ Personal distress } & $\mathrm{M}$ & 20.93 & 18.55 & 1.82 & 78 & .073 \\
\hline & SD & 5.98 & 5.66 & & & \\
\hline \multirow[t]{2}{*}{ Taking perspective } & $\mathrm{M}$ & 36.02 & 33.00 & 2.85 & 78 & $.006^{* *}$ \\
\hline & $\mathrm{SD}$ & 5.19 & 4.20 & & & \\
\hline
\end{tabular}

$* p \leq .05 ; * * p \leq .01$

Table IV. The level of emphatic sensitivity by gender with the summary of t-test statistics.

Source: Own work.

\begin{tabular}{|c|c|c|c|c|c|c|c|c|c|c|}
\hline & & \multicolumn{5}{|c|}{ Age } & \multicolumn{4}{|c|}{ Analysis of variance ANOVA } \\
\hline & & $<\mathbf{3 0}$ & $\begin{array}{l}31-40 \\
\text { years }\end{array}$ & $\begin{array}{l}41-50 \\
\text { years }\end{array}$ & $\begin{array}{l}51-60 \\
\text { years }\end{array}$ & $61<$ & $\boldsymbol{F}$ & $d f$ & $p$ & $\eta^{2}$ \\
\hline \multirow[t]{2}{*}{ Empathic concern } & M & 39.31 & 39.12 & 41.59 & 41.63 & 41.33 & 0.55 & 4.75 & .70 & 0.029 \\
\hline & SD & 5.45 & 7.06 & 7.08 & 5.07 & 10.97 & & & & \\
\hline \multirow[t]{2}{*}{ Personal distress } & M & 20.25 & 20.12 & 18.36 & 21.19 & 19.44 & 0.58 & 4.75 & .68 & 0.030 \\
\hline & SD & 5.00 & 6.12 & 6.27 & 5.26 & 7.63 & & & & \\
\hline \multirow[t]{2}{*}{ Taking perspective } & $\mathrm{M}$ & 35.00 & 33.76 & 33.45 & 35.06 & 37.33 & 1.17 & 4.75 & .33 & 0.059 \\
\hline & SD & 4.68 & 5.11 & 4.15 & 5.20 & 6.26 & & & & \\
\hline
\end{tabular}

${ }^{*} p \leq .05$

Table V. The level of emphatic sensitivity by gender including the summary of ANOVA statistics.

Source: Own work.

Post-hoc comparisons with the Fisher LSD test revealed the existence of statistically significant differences between female doctors with specialization in clinical oncology and female doctors specializing in internal diseases (CONK < ID). Significantly higher values of average results for emphatic susceptibility have been observed on the Scale of Personal Distress in female doctors specializing in radiology and diagnostic imaging in relation to female doctors specializing in clinical oncology (RDI > CONK). The data is presented in Table VIII.

In order to determine the level of empathic sensitivity for three subscales by gender, age and physican's specialty, the values of average results were converted into sthens (Table IX). Such a possibility is not provided by the analysis of average results because of the discrepancies in values of intervals assigned to particular sthene levels, different for male and female doctors. The findings have been presented in the DISCUSSION OF RESULTS AND CONCLUSION section.

\section{Discussion of results and conclusion}

The conducted analysis revealed the results of emphatic sensitivity in doctors in regard to gender, age and specialty on the Scale of Emphatic Concern, Personal Distress and Taking Perspective. As far as Emphatic Con- 


\begin{tabular}{|c|c|c|c|c|c|c|c|c|}
\hline & \multirow[b]{2}{*}{ Medical specialty } & \multirow[b]{2}{*}{$\mathbf{M}$} & \multirow[b]{2}{*}{ SD } & \multicolumn{3}{|c|}{$\begin{array}{c}\text { Analysis of variance } \\
\text { ANOVA }\end{array}$} & \multirow[b]{2}{*}{$\eta^{2}$} & \multirow{2}{*}{$\begin{array}{c}\text { Comparison } \\
\text { post hoc }\end{array}$} \\
\hline & & & & $\boldsymbol{F}$ & $d f$ & $p$ & & \\
\hline \multirow{11}{*}{ 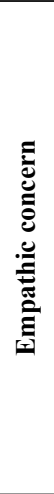 } & Anesthesiology and intensive care/critical care & 44.50 & 6.60 & 1.81 & 10.79 & .07 & 0.028 & - \\
\hline & Surgery & 44.09 & 6.66 & & & & & \\
\hline & Internal medicine & 36.44 & 5.22 & & & & & \\
\hline & Oncological gynecology & 39.88 & 6.45 & & & & & \\
\hline & Clinical oncology & 38.60 & 7.60 & & & & & \\
\hline & Pediatrics & 46.40 & 4.56 & & & & & \\
\hline & Gynecology and obstetrics & 37.88 & 8.53 & & & & & \\
\hline & Pulmonary medicine & 43.83 & 5.34 & & & & & \\
\hline & Radiology and diagnostic imaging & 39.29 & 7.34 & & & & & \\
\hline & Oncological radiotherapy & 40.60 & 5.73 & & & & & \\
\hline & Without specialty & 37.90 & 6.49 & & & & & \\
\hline \multirow{11}{*}{ 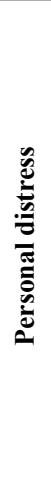 } & Anesthesiology and intensive care/critical care & 16.67 & 2.42 & 1.39 & 10.79 & .20 & 0.168 & \\
\hline & Surgery & 17.82 & 5.55 & & & & & \\
\hline & Internal medicine & 18.89 & 7.25 & & & & & \\
\hline & Oncological Gynecology & 19.75 & 6.48 & & & & & \\
\hline & Clinical oncology & 16.20 & 4.32 & & & & & \\
\hline & Pediatrics & 23.00 & 3.24 & & & & & \\
\hline & Gynecology and obstetrics & 17.63 & 4.14 & & & & & \\
\hline & Pulmonary medicine & 20.33 & 5.43 & & & & & \\
\hline & Radiology and diagnostic imaging & 22.57 & 7.52 & & & & & \\
\hline & Oncological radiotherapy & 23.60 & 7.09 & & & & & \\
\hline & Without specialty & 37.90 & 6.49 & & & & & \\
\hline \multirow{11}{*}{ 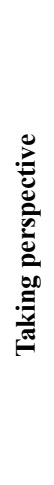 } & Anesthesiology and intensive care/critical care & 35.17 & 3.60 & 2.26 & 10.79 & $.02 *$ & 0.247 & WS $<$ PED \\
\hline & Surgery & 35.36 & 4.23 & & & & & $\mathrm{PED}>\mathrm{OR}$ \\
\hline & Internal medicine & 36.56 & 5.73 & & & & & \\
\hline & Oncological gynecology & 33.88 & 4.88 & & & & & \\
\hline & Clinical oncology & 34.20 & 6.06 & & & & & \\
\hline & Pediatrics & 40.40 & 4.10 & & & & & \\
\hline & Gynecology and obstetrics & 32.00 & 4.60 & & & & & \\
\hline & Pulmonary medicine & 35.67 & 4.23 & & & & & \\
\hline & Radiology and diagnostic imaging & 36.57 & 3.41 & & & & & \\
\hline & Oncological radiotherapy & 30.80 & 3.03 & & & & & \\
\hline & Without specialty & 31.40 & 5.06 & & & & & \\
\hline
\end{tabular}

$* p \leq .05$

Table VI. The level of emphatic sensitivity by types of medical specialization including the summary of ANOVA statistics.

Source: Own work.

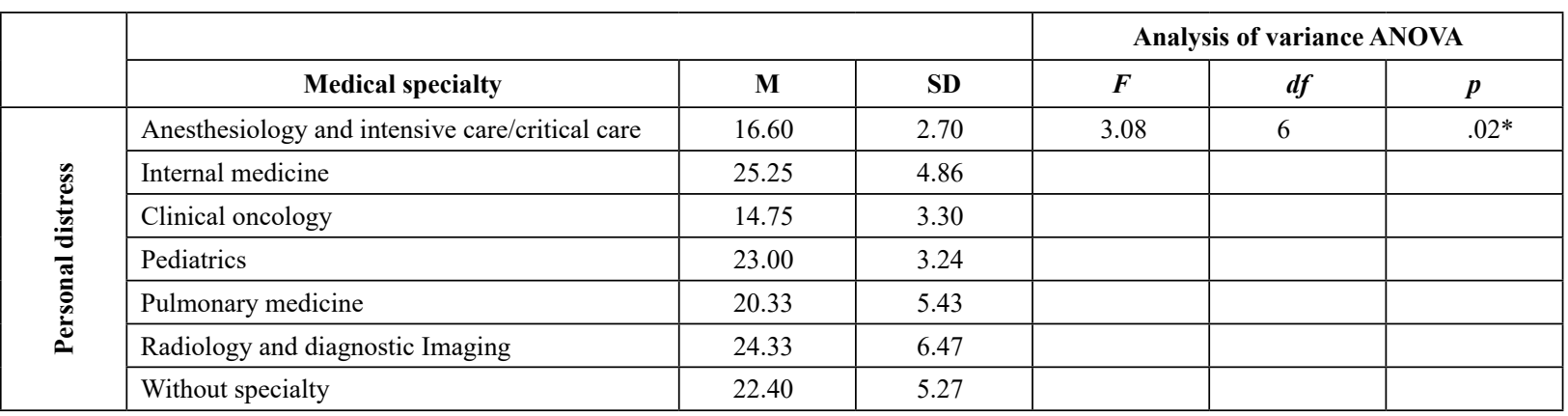

$* p \leq .05$

Table VII. The level of emphatic sensitivity on the Personal Distress Scale by specialty in female doctors including the summary of ANOVA statistics.

Source: Own work. 


\begin{tabular}{|c|c|c|c|c|c|c|c|}
\hline $\begin{array}{c}\text { POST-HOC } \\
\text { (Fisher LSD) } \\
\quad p \text { value }\end{array}$ & $\begin{array}{l}\text { Anesthe- } \\
\text { siology and } \\
\text { intensive } \\
\text { care/critica- } \\
\text { licare }\end{array}$ & $\begin{array}{l}\text { Internal } \\
\text { medicine }\end{array}$ & $\begin{array}{c}\text { Clinical } \\
\text { oncology }\end{array}$ & Pediatrics & $\begin{array}{l}\text { Pulmonary } \\
\text { medicine }\end{array}$ & $\begin{array}{c}\text { Radiology } \\
\text { and diagno- } \\
\text { stic imaging }\end{array}$ & $\begin{array}{l}\text { Without } \\
\text { specialty }\end{array}$ \\
\hline $\begin{array}{l}\text { Anesthesiology } \\
\text { and intensive care/ } \\
\text { critical care }\end{array}$ & & 0.011859 & 0.569426 & 0.043704 & 0.20863 & 0.012605 & 0.065848 \\
\hline Internal medicine & 0.011859 & & $0.00438 * *$ & 0.489606 & 0.123065 & 0.769082 & 0.382705 \\
\hline Clinical oncology & 0.569426 & $0.00438 * *$ & & 0.015883 & 0.081746 & $0.00439 * *$ & 0.024332 \\
\hline Pediatrics & 0.043704 & 0.489606 & 0.015883 & & 0.365796 & 0.64932 & 0.844449 \\
\hline $\begin{array}{l}\text { Pulmonary } \\
\text { medicine }\end{array}$ & 0.20863 & 0.123065 & 0.081746 & 0.365796 & & 0.159212 & 0.482081 \\
\hline $\begin{array}{l}\text { Radiology and } \\
\text { diagnostic imaging }\end{array}$ & 0.012605 & 0.769082 & $0.00439 * *$ & 0.64932 & 0.159212 & & 0.510555 \\
\hline Without specialty & 0.065848 & 0.382705 & 0.024332 & 0.844449 & 0.482081 & 0.510555 & \\
\hline
\end{tabular}

$* * p \leq .01$

Table VIII. The significance of differences on the basis of Fisher's LSD post-hoc test presenting the level of emphatic sensitivity on the Personal Distress Scale by specialization in women.

Source: Own work.

\begin{tabular}{|c|c|c|c|c|}
\hline & & Empathic concern & Personal distress & Taking perspective \\
\hline \multirow{2}{*}{ ذँّ } & Female & average & low & high \\
\hline & Male & average & low & average \\
\hline \multirow{5}{*}{ 总 } & $<30$ years & average & low & average \\
\hline & $31-40$ years & average & low & average \\
\hline & $41-50$ years & average & low & average \\
\hline & $51-60$ years & average & low & average \\
\hline & $61<$ & average & low & high \\
\hline \multirow{11}{*}{ 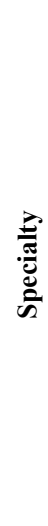 } & Anesthesiology and intensive care & high & low & average \\
\hline & Surgery & high & low & average \\
\hline & Internal medicine & low & low & high \\
\hline & Oncological gynecology & average & low & average \\
\hline & Clinical oncology & average & low & average \\
\hline & Pediatrics & high & average & high \\
\hline & Gynecology and obstetrics & average & low & average \\
\hline & Pulmonary disease & average & low & average \\
\hline & Radiology and diagnostic imaging & average & low & high \\
\hline & Oncological radiotherapy & average & average & average \\
\hline & Without specialty & average & average & average \\
\hline
\end{tabular}

Table IX. The levels of emphatic sensitivity for three subscales by gender, age and specialty.

Source: Own work.

cern is concerned, both male and female doctors obtained average results, which may indicate their average willingness to engage in relations with patients and the fact that they show a moderate need for closeness and kindness towards the patients. A person with an average Emphatic Concern (EC) level does not always reveal a tendency to experience anxiety or worry; they are also unwilling to display enthusiasm in relation to patients. The average level of EC may indicate a fair level of satisfaction from the interaction with patients and that they treat them with little reserve. Patients often talk about their personal problems and they expect compassion and consolation 
from their physicians; however the average level of EC may indicate that such a situation does not produce excessive worry in them. Average values on the Emphatic Concern Scale do not necessarily predispose them to the emotional engagement in their patients' problems and may indicate moderate sympathy towards a patient. It is also difficult to assess to what extent the events they observe move them and also, to what extent they feel concern in relation to people who have been wronged by life. Neither is it possible to find out if doctors with such a level of emphatic sensitivity on the Scale of Empathic Concern are ready for emotional engagement into their patients' problems.

Personal Distress developed at a low level in male and female doctors alike. In the medical profession this level can guarantee the lack of risk of burnout. The researched doctors are unlikely to be exposed to excessive anxiety which could lead in turn to disorders in the social sphere and a tendency to irritability or constant nervous tension. The medical profession makes a demand for an enormous amount of understanding and patience in relation to a patient and their struggle against an illness. Unfortunately, a low level of PD may indicate the lack of sensitivity, which may be badly taken by people making use of medical services. A negative correlation of Personal Distress with social boldness may enhance, in this case, the ease in public appearance, highten their self-esteem and dispel the fear of change taking place in the environment. A low level of Personal Distress may define physicians as the people who do not experience high tension or emotional hostility. The lack of helplessness in a physician results in the rise of the sense of security in a patient, thus creating the sense of reliability of the services provided by medical staff. A low level of Personal Distress may confirm emotional stability of physicians who do not lose selfcontrol or self-confidence in difficult situations.

Analysing the results on the Taking Perspective subscale it can be stated that a tendency to a spontaneous acceptance of the psychological point of view of patients developed in female doctors at a high level, whereas in male doctors - at an average level. Kindness towards patients and understanding are personal characteristics which the patients would desire to see in the people they entrust their fate. The average level of the above mentioned features as well as a moderate level of courage in interpersonal relations and opening to others may be considered by patients as a sign of meager interest in their problems. Women with high Taking Perspective (TP) score will be considered by patients as people ready for cooperation in their strife against an illness and interested in emotional experiences of their patients. The average level of TP does not allow to define clearly if male doctors are inclined to experience anxiety and worry as well as to what extent they derive satisfaction from interaction with other people. A different situation can be observed in female doctors whose high level of TP will show that they draw high professional satisfaction. It is impossible to confirm that men want to influence patients, take risk in treatment and to find out to what extent they are emotionally resilient. The above mentioned behaviours will undoubtedly characterise women whose emotional resilience will surpass the resilience in men. Average values for Taking Perspective may indicate moderately good interpersonal skills in male doctors who generally do not concentrate on the causes of actions but their consequences. Female doctors will display much better developed interpersonal skills and they will pay more attention to the causes of actions than men. The researched men displayed an average ability to empathize with their patients in contrast to women whose need to understand the situation of patients is much higher. Obtaining the average PF level by men may mean neutrality in relation to someone's behaviour and understanding its cause. Besides, it is hard to judge if they always try to look at possible misunderstandings with patients from the perspective of the latter. A high score on the TP scale predisposes women to establish contact with patients with more ease. They also try to get to the core of the existing conflict.

The analysis of particular scales of empathic sensitivity in relation to specialty helps to observe a variety in the levels of doctor's ability to empathize with patients. It has been noted that statistically a medical specialty differentiates significantly the TP level. The greatest differences in average results referred to doctors with specialty in oncological radiotherapy (the lowest score) as well as in pediatrics and physicians in the course of doing their specialty (the highest score). These differences may be caused by a different type of work performed on the ward and by the fact that they take care of a different type of patient. A lower score of an oncological radiotherapist may result from their attempt to block an inclination to experience distress and discomfort in response to very negative experience with patients in extremely serious condition, often in a terminal phase. The most difficult element of performing medical profession is working with a dying patient, in particular in situations when the dying patient resembles or brings to mind a person the physician is emotionally involved with, e.g. a family member. Being continuously surrounded by terminally ill people may increase a nervous tension which additionally derives from the awareness that no effective treatment is available.

A pediatrician's little patient expects from his medical carer a lot of understanding, warmth and sharing emotions; both positive and negative ones. It is difficult for children to understand their own situation when undergoing painful and comfortless diagnostic procedures. Anxiety accompanying them all the time has a negative outcome on the whole process of treatment. Pediatricians who admit satisfaction from the interaction with little patients prove their interpersonal skills. Children expect openness and understanding from a physician. The highest average TP results scored by pediatricians may indicate their enormous flexibility and the ability to adjusts to the needs of little patients.

On the basis of the conducted research it has been concluded that the researched physicians get engaged in relations with patients in a sensible way. The respondents can skillfully dispense their sensitivity, spontaneity and enthusiasm. The ability to control their own emotionality 
can protect therapists from professional burnout which in consequence might lead to a different type of addictions, neurosis, depression or even resignation from work.

The research findings were compared with the results of research depicting the level of satisfaction carried out on patients from the one of the hospitals in Gdynia in 2012. In the above mentioned research the most important elements affecting patient satisfaction were determined by:

- the amount of time devoted by a physician $(\mathrm{SRu}=$ 19675.00, $\mathrm{SRn}=2480.000, U=1885.00, p=.000$, $\mathrm{r}=0.27$ );

- the physician's politeness $(\mathrm{SRu}=19567.00, \mathrm{SRn}=$ 2588.000, $U=1993.00, p=.000, \mathrm{r}=0.27$;

- explanations and information provided by a physician $(\mathrm{SRu}=19485.50, \mathrm{SRn}=2669.500, U=2074.50, p=$ $.001, \mathrm{r}=0.23)$ [18].

Part of the research findings presented above may confirm the significance of these elements in the assessment of a medical establishment which have a considerable influence on patients' satisfaction. Three elements which received the highest score by the respondents have created a model of an emphatic doctor; polite and full of kindness in relation to a patient and who may devote as much of their time to the patient as necessary and also to create in them the sense of safety. An emphatic physician will have the ability to provide a patient with adequate information and clear explanation about the condition of their health to meet their need for information and to do it in the most approachable way.

\section{Conclusion}

An important determinant of the quality of a doctorpatient relationship is specified by the speed of the therapist's reaction to the patient's needs as well as his ability to create the sense of safety for the patient when in a difficult situation, in an alien environment and facing uncertainty connected with their treatment [19]. Empathy emerges from our self-awareness. The more we are open to our own emotions, the more effectively we interpret the emotions in others [1].

It is every patient's wish to have a highly empathic physician who would be willing to share feelings with a patient and their hardships connected with an illness. Then, the patient would know that they are understood and supported in this, at times, unequal fight. The physician's emphatic attitude would increase the patient's trust and would allow to establish better interpersonal contacts thus improving the effectiveness of the process of treatment. Unfortunately, physicians are currently forced to deal with a difficult situation in the healthcare system , they are overloaded with a huge number of patients and with writing medical records.

The better we empathize with a person in need and understand their problems, the more concern we show and the stronger our willingness to help that person. The danger comes when we feel the emotions of others to a small extent only; then we become capable of ignoring their suffering. A blockage against emotional infection becomes a destructive element of the relations with other people. In such circumstances man is capable of creating a safe social distance [9]. To avoid depression caused by empathy, medical staff try to resist sensitivity caused by the suffering of others and attempt to create an emotional shell [3]. The doctor's task is to select the right medical activities to cure a patient. To achieve their aim, which is the patient's recovery, the use of the following emotions can prove very helpful: happiness, hope, optimism, a bond with the patient, affiliation to a group who directly understand each of their members and empathy. People content with life, and optimistic about the activity they are expected to perform are ready to make every effort in pursuit of their goal [20].

The awareness of all the messages sent by a patient, with sensitivity to their reception and emission, may trigger the beginning of good communication with the patient which, in consequence, will undoubtedly speed up and improve the process of treatment. A correct therapeutic patient - doctor relationship should be based on honesty towards the patient and openness to their needs. One should not forget the need to adjust a verbal exchange to the patient's personality and construct it in such a way that it is well received by the patient. The doctor should inspire hope, and reduce fear and doubt. The patient should be certain that the treatment to which he is subjected is the best.

Nowadays the patient is treated by an increasing number of doctors and that is why he becomes an "impersonal tool" in the hands of the latter. The need for empathy from the person in whose hands we entrust our potential health, and sometimes even life, is enormous and is encreasingly desired. Patients expect from their doctor to be able to feel their emotions, identify with their pain and understand their problems. However, the doctor faces the greatest challenge from negative emotions. Both patients and doctors experience anxiety. Patients are afraid of the effects of their illness and the results of treatment. The most difficult emotions become a share of patients who learn that their illness is terminal. The anxiety experienced by a doctor is foremost connected with the failure of the applied treatment. However, it also applies to possible communication problems with patients and their families, the attempts of the patient to dominate the doctor as well as the lack of access to research, methods of treatment and death.

While expecting from doctors a wide range of skills, one has to be aware of the possible consequences they may bring. On the one hand, they will fulfil a dream of every patient of a devoted doctor who understands all the problems and meets their expectations, a doctor who can listen actively and supports the patient during a difficult strife in the diagnostic process, a doctor who helps them to go through the whole process of treatment and its effects with dignity, with a sense of security. As a result of contact with an emphatic doctor, the patient will reach a high level of satisfaction and the satisfaction will be transferred into the whole medical establishment. A satisfied patient will recommend such an institution to his family and friends. All emphatic forms of behaviour of 
the doctor will increase the psychological and physical comfort of patients staying on hospital wards. A negative side of the high level of empathy may be long-lasting emphatic depression caused by too strong emotional commitment of the doctor to the patient's problems and the lack of self-regulatory skills. The inability to cope with an emotional burden and unwillingness to use the help of psychotherapists may lead to the development of professional burnout which, in turn, may lead to significant occupational disruption such as bad quality of the provided services, going regularly on a sick leave, withdrawal from the life of the medical unit and even healthcare. A dissatisfied patient will be looking for medical help in another facility, depriving the hospital the possibility of further development through the reduction of the number of contracted procedures and depriving the entity of its influence on the shaping of the medical services market.

Empathy requires continuous improvement by making use of the acquired emotional experience, and the ability to interact with others leads to job satisfaction, deprives people of egoism, strengthens family and professional bonds and widens the horizons [21].

\section{References}

1. Goleman D., Inteligencja emocjonalna, Media Rodzina, Poznań 2007.

2. Krokowski M., Rydzewski P., Zarzadzanie emocjami, Imperia, Łódź 2006.

3. Goleman D., Inteligencja emocjonalna $w$ praktyce, Media Rodzina, Poznań 2007.

4. Kliszcz J., Empatia a relacja lekarz - pacjent, in: Barański J., Waszyński E., Steciwko A. (eds.), Komunikowanie się lekarza z pacjentem, Wydawnictwo Astrum, Wrocław 2017.

5. Davis M.H., Empatia. O umiejętności współodczuwania, Gdańskie Wydawnictwo Psychologiczne, Gdańsk 2001.

6. Włodarczyk D., Skuza B., Znaczenie relacji pacjent-personel medyczny dla przebiegu leczenia, in: Jakubowska-Winecka A., Włodarczyk D. (eds.), Psychologia w praktyce medycznej, Wydawnictwo Lekarskie PZWL, Warszawa 2007.

7. Jankowiak-Siuda K., Siemieniuk K., Grabowska A., Neurobiologiczne podstawy empatii, "Neuropsychiatria i Neuropsychologia" 2009; 4 (2): 51-58.
8. Kaźmierczak M., Empatia w strukturach organizacyjnych, "Roczniki Psychologiczne" 2004; 7 (2): 131-144.

9. Goleman D., Inteligencja spoleczna, Dom Wydawniczy „Rebis”, Poznań 2007.

10. Hebanowski M., Kliszcz J., Trzeciak B., Poradnik komunikowania się lekarza z pacjentem, Wydawnictwo Lekarskie PZWL, Warszawa 2005.

11. Bąk-Sosnowska M., Choroba w życiu człowieka, in: Trzcieniecka-Green A. (ed.), Psychologia, podręcznik dla studentów kierunków medycznych, Towarzystwo Autorów i Wydawców Prac Naukowych „Universitas”, Kraków 2012.

12. Gordon T., Edwards W.S., Pacjent jako partner, Instytut Wydawniczy PAX, Warszawa 1999.

13. Jakubowska-Winecka A., Zespół wypalenia zawodowego, in: Jakubowska-Winecka A., Włodarczyk D. (eds.), Psychologia w praktyce medycznej, Wydawnictwo Lekarskie PZWL, Warszawa 2007.

14. Salmon P., Psychologia w medycynie, Gdańskie Wydawnictwo Psychologiczne, Gdańsk 2002.

15. Wons A., Wypalenie zawodowe, in: Trzcieniecka-Green A. (ed.), Psychologia. Podręcznik dla studentów kierunków medycznych, Towarzystwo Autorów i Wydawców Prac Naukowych „Universitas”, Kraków 2006.

16. Tobiasz-Adamczyk B., Relacje lekarz-pacjent w perspektywie socjologii medycyny, Wydawnictwo Uniwersytetu Jagiellońskiego, Kraków 2002.

17. Kaźmierczak M., Plopa M., Retowski S., Skala Wrażliwości Empatycznej, "Przegląd Psychologiczny" 2007; 50 (1): 9-24.

18. Królak S., Wplyw marketingu ustug medycznych na satysfakcje pacjenta na przyktadzie Szpitala Morskiego im. PCK w Gdyni, Wyższa Szkoła Administracji i Biznesu, Gdynia 2013.

19. Bukowska-Piestrzyńska A., Marketing usług zdrowotnych. Od budowania wizerunku placówki do zadowolenia klientów, CeDeWu, Warszawa 2012.

20. Franken R.E., Psychologia motywacji, Gdańskie Wydawnictwo Psychologiczne, Gdańsk 2006.

21. Królak S., Empatia u lekarzy jako element efektywnej komunikacji z pacjentem, Wyższa Szkoła Administracji i Biznesu, Gdynia 2012.

Przygotowanie do wydania elektronicznego publikacji - zadanie finansowane w ramach umowy Nr 780/P-DUN/2017 ze środków Ministra Nauki i Szkolnictwa Wyższego przeznaczonych na działalność upowszechniająca naukę. 